\title{
The Reach of Linear Protein-DNA Dimerizers
}

\author{
Ryan L. Stafford and Peter B. Dervan \\ Contribution by the Division of Chemistry and Chemical Engineering, California Institute of \\ Technology, 1200 E. California Blvd., Pasadena, California 91125
}

\section{Abstract}

A protein-DNA dimerizer constructed from a DNA-binding pyrrole-imidazole polyamide and the peptide FYPWMK facilitates binding of the natural transcription factor Exd to an adjacent DNA site. Previous dimerizers have been constructed with the peptide attached to an internal pyrrole monomer in an overall branched oligomer. Linear oligomers constructed by attaching the peptide to the polyamide C-terminus expand the range of protein-DNA dimerization to six additional DNA sites. Replacing the FYPWMK hexapeptide with a WM dipeptide, which was previously functional in branched compounds, does not lead to a functional linear dimerizer. Instead, inserting an additional lysine generates a minimal, linear WMK tripeptide conjugate that maintains the activity of the larger FYPWMK dimerizers in a single DNA-binding site orientation. These studies provide insight into the importance of linker length and composition, binding site spacing and orientation, and the proteinbinding domain content that are important for the optimization of protein DNA-dimerizers suitable for biological experiments.

\section{Introduction}

Transcription in living cells is controlled by precise spatial and temporal recognition of DNA by protein transcription factors. ${ }^{1}$ These proteins often bind to DNA as homo- and heterodimers or larger complexes which increases their overall DNA-binding site size, specificity, and affinity. ${ }^{2}$ Transcription factors are usually modular, whereby the DNA-binding and dimerization, or protein-binding domains, are functionally and structurally independent. ${ }^{3}$ Small molecules called artificial transcription factors have been reported to mimic the modular components of these endogenous proteins. ${ }^{4}$ Protein-DNA dimerizers are a type of artificial transcription factor which facilitate binding of proteins to an adjacent DNA site, mimicking natural multiprotein-DNA complexes. ${ }^{5}$ Our long-term goal is to ask whether protein-DNA dimerizers can serve as artificial regulators of gene expression in a living cell. From a design point of view, we are exploring what is the minimum size and shape (branched or linear) that will be optimal for cell uptake with adequate functional potency in the transcriptional apparatus. It has been previously shown that branched dimerizers facilitate protein-binding at three different binding sites (Figure 1a). ${ }^{5 \mathrm{c}}$ Here, we describe linear structural motifs which expand the number of recognition sites targetable by protein-DNA dimerizers. The optimal DNA site spacings and necessary protein-binding elements have also been determined, which culminated in the discovery of a minimal, three amino acid protein-binding domain that yields strong dimerization at DNA-binding sites reaching 6 base pairs apart.

Protein-DNA dimerizers can mimic homeobox (HOX) transcription factors by binding cooperatively to DNA with the protein extradenticle (Exd). ${ }^{5}$ The conserved class of HOX transcription factors is known to bind relatively short DNA sites by themselves, but in complex with co-factor proteins, they bind larger DNA sequences. ${ }^{6}$ The increase in their composite 
DNA recognition site is thought to be important for their function in developmental pathways.

${ }^{6}$ For instance in D. melanogaster, the HOX protein ultrabithorax (Ubx) binds the site $5^{\prime}$ -

TTAT-3' alone, but in complex with Exd the composite site increases by four base pairs to 5'TGATTTAT-3'. ${ }^{\prime}$ a A crystal structure of the ternary Ubx/Exd/DNA complex revealed how both Ubx and Exd's major groove binding homeodomains interact via Ubx's N-terminal YPWM peptide motif. ${ }^{7 \mathrm{a}}$ The conserved YPWM motif spans the DNA minor groove between the two proteins and inserts a hydrophobic tryptophan into the complementary Exd binding pocket. Additional crystal structures of HoxB1/Pbx/DNA and HoxA9/Pbx/DNA which contain human homologues of Ubx and Exd have also been reported in which the conserved tryptophan of the YPWM motif mediates the majority of the protein-protein contacts. ${ }^{7 b-c}$ Protein-DNA dimerizers have been constructed by replacing the natural DNA-binding homeodomain of Ubx with a synthetic pyrrole-imidazole polyamide which binds the DNA minor groove. ${ }^{5}$

Polyamides are ideal small-molecule DNA binding domains since they can be programmed to bind to a broad repertoire of sequences using an aromatic amino acid pairing code ${ }^{8 \mathrm{a}-\mathrm{b}}$ Hairpin polyamides by themselves have shown the ability to inhibit protein-DNA complex formation in biological contexts. ${ }^{8 \mathrm{c}-\mathrm{d}}$ Protein-DNA dimerizers have the potential to be more specific regarding cellular targets relative to parent hairpin DNA binders by virtue of their ability to bind larger cognate DNA sites with proteins and through incorporation of a unique proteinbinding recognition interface.

In this study we explore the range of DNA sites in which Exd-DNA dimerization is observed in the presence of linear polyamide-peptide conjugates using a series of DNA duplexes containing incremental A,T base pair spacings between the polyamide and Exd binding sites. Linear oligomers were generated by attaching an FYPWMK peptide to the polyamide Cterminus incorporating linkers of different lengths and composition, i.e. 1 and $\mathbf{2}$ (Figure 2). The synthesis of linear conjugates is simpler than branched ones since the peptide can be coupled directly to a standard pyrrole-imidazole polyamide without the need for the synthesis of advanced building blocks. Once the scope of recognition sequences with these larger constructs was defined, efforts were made to discover a minimal protein-binding domain for dimerizers in this linear configuration. It is shown that WM dipeptides (with both $\mathrm{L}$ and $\mathrm{D}$ stereochemistry of the W) which previously enhanced Exd-DNA binding in the branched oligomer ${ }^{5 \mathrm{~d}}$ failed to yield stable Exd-DNA complexes. Exd dimerization activity was recovered by inserting a lysine back into the peptide to generate minimal WMK tripeptide conjugates. The presence of a positively charged ammonium ion in the linker and lysine seem to be favorable for complex formation possibly due to interactions with the negatively charged DNA backbone.

\section{Results and Discussion}

\section{Dimerization in Proximal and Distal Orientations}

Exd is expected to bind $5^{\prime}$-TGAT- $3^{\prime}$ as found in the Ubx/Exd/DNA crystal structure ${ }^{7 \mathrm{a}}$ and the hairpin polyamide ImImPyPy- $\gamma$-PyPyPyPy- $\beta$-codes for the sequence $5^{\prime}$-WGGWWW- $3^{\prime}$ ( where $\mathrm{W}=\mathrm{A}$ or $\mathrm{T}$ ). ${ }^{8 \mathrm{a}-\mathrm{b}}$ In the proximal orientation, the polyamide binding site is oriented such that the protein-binding YPWM peptide is projected adjacent to Exd (Figure 1b). In the distal orientation, the polyamide binding site was inverted such that the peptide is projected away from Exd (Figure 1c). For dimerization of Exd at a given DNA site to occur, the proteinbinding peptide must project over the DNA phosphate backbone and interact favorably with the binding pocket of the major groove binding Exd protein (Figure 1d). Dimerization was expected to be dependent on both the length and composition of the linker between the polyamide and the YPWM-containing peptide as well as the size of the spacer region between the polyamide's and protein's binding sites. 
Accordingly, two polyamide-peptide conjugates were constructed that incorporated either a tertiary amine (1) or a PEG linker (2). The distance between the terminal amine of the linker to the carbonyl carbon of the methionine of the peptide was determined computationally in the gas-phase for MM2-energy minimized linkers to be approximately 23 and $30 \AA$ for $\mathbf{1}$ and $\mathbf{2}$, respectively. A series of DNA duplexes which contained an incremental A,T spacer region were screened by electrophoretic mobility shift (EMSA), or gel shift assays, to determine the range of protein recruitment to the DNA at room temperature $\left(20^{\circ} \mathrm{C}\right)$. A total of nine different duplexes (47-55 bps) in the proximal orientation with spacer regions between -1 and $7 \mathrm{bps}$ were used, covering distances between the polyamide and expected protein-binding domain position from approximately 11 to $30 \AA$. Negative spacer regions indicate an overlap in the expected binding sites.

It might be expected that since $\mathbf{2}$ contains a longer linker than $\mathbf{1}$, it would facilitate Exd binding at sites further away from the polyamide binding site. Instead, it was observed that $\mathbf{1}$ dimerizes Exd effectively on composite sites containing spacer regions between 2 to 6 base pairs, whereas 2 only dimerizes Exd on sites with spacer regions of 4 to 5 base pairs (Figure 3 and Table 1). Thus, compound $\mathbf{2}$ has a narrower recognition profile, in contrast to $\mathbf{1}$ which is more promiscuous. The greater tolerance for multiple binding sites by compound $\mathbf{1}$ may be due to its chemical composition. It is possible that the presence of the positively charged ammonium ion in $\mathbf{1}$ may interact more favorably with the phosphate backbone than the PEG linker of $\mathbf{2}$. Additionally, the dihedral angles along the $-\mathrm{OCH}_{2} \mathrm{CH}_{2} \mathrm{O}$ - axes of $\mathrm{PEG}$ are known to favor gauche conformations which is expected to form a partially helical linker spanning approximately $24 \AA$ in the context of 2 . $^{9}$ There is probably an energetic barrier along the transition from a helical, all-gauche conformation to the fully-extended, all-trans form that explains why no dimerization is observed at distances greater than $24 \AA$. Control experiments at all of these sites show that Exd by itself, or in the presence of parent polyamide ImImPyPy$\gamma$-PyPyPyPy- $\beta$-Dp 15, or the double alanine mutants 3 and 4, does not lead to stable complex formation (Supplemental Figure 1). Thus, the polyamide domain by itself does not appear to contribute to the binding of Exd through allosteric interactions as observed in previously reported systems. $5 \mathrm{~d}$ Furthermore, these control experiments show that dimerization of Exd is dependent on the central tryptophan and methionine residues in this context.

In the distal orientation, 5 different spacer regions ( 5 duplexes, $46-50 \mathrm{bps}$ ) were investigated from -2 to 2 bps covering a theoretical distance of approximately 15 to $30 \AA$ between the polyamide and expected protein-binding domain position. In this arrangement, Exd dimerization was observed only with compound $\mathbf{1}$ at the -2 spacer site (Figure 4 and Table 2). Control experiments at the -2 site show that Exd by itself, in the presence of parent polyamide ImImPyPy- $\gamma$-PyPyPyPy- $\beta$-Dp 15, or double alanine mutant 3, does not lead to stable complex formation (Supplemental Figure 2).

\section{Minimization of the Protein-binding Domain}

As mentioned above, we have previously reported that in the context of a branched polyamidepeptide conjugate, the protein-binding domain could be reduced to a WM dipeptide. $5 \mathrm{~d}$ Thus, compounds 5-8 were synthesized to see if an analogous linear dipeptide conjugate would also dimerize Exd. Gel shift experiments with 5 and $\mathbf{6}$ using DNA duplexes with spacings of 0 to 6 in the proximal orientation, and -2 in the distal orientation did not lead to any significant gel shift (Supplemental Figure 3). A weak complex was observed with compound 6 at the 3 bp proximal spacing $\left(\Theta_{\text {app }}=0.3 \pm 0.1\right.$ at $100 \mathrm{nM}$ Exd and $\left.50 \mathrm{nM} 6\right)$, but was not significant enough to reliably determine the Exd-DNA binding affinity. Similarly, the WM conjugates bearing the PEG linker (7 and 8) failed to yield any discernible gel shift with DNA duplexes containing proximal spacings of 1 to $6 \mathrm{bps}$ or at the $-2 \mathrm{bp}$ distal spacing (Supplemental Figure 3). 
It was noted that the substitution of FYPWMK (1 and 2) with WM (5-8) eliminated the lysine between the presumed linker domain and the core WM dipeptide of the YPWM motif. Thus, WMK tripeptide conjugates 9-12 were synthesized to ensure identical linker length and composition between the polyamide and the WM moiety. These compounds were examined by gel shift using duplexes with proximal spacings between 3 and 6 bps shown above to enable dimerization of Exd with the larger conjugates $\mathbf{1}$ and $\mathbf{2}$. Both tertiary amine containing WMK conjugates ( $\mathbf{9}$ and $\mathbf{1 0})$ yielded a complex with Exd only at the 6 bp proximal site, but the PEG containing WMK conjugates (11 and 12) did not lead to an observable shift in any of the orientations (Figure 5 and Supplemental Figure $4 \mathrm{~b}$ ). Both $\mathbf{9}$ and $\mathbf{1 0}$ at the proximal $6 \mathrm{bp}$ spacing site yielded similar binding affinities $\left(\mathrm{K}_{\mathrm{a}}=9.2 \pm 0.6 \times 10^{8} \mathrm{M}^{-1}\right.$ and $7 \pm 2 \times 10^{8} \mathrm{M}^{-1}$, respectively) and amounts of complex formed ( $0.50 \pm 0.01$ and $0.53 \pm 0.05$, respectively) indicating no significant difference in Exd binding by either the L- or D-tryptophan peptides in this context. The binding affinities of Exd in the presence of $\mathbf{9}$ and $\mathbf{1 0}$ are within 4-fold of those observed for the larger conjugates $\mathbf{1}$ and $\mathbf{2}$ (Tables 1 and 2). In comparing $\mathbf{9}$ and $\mathbf{1 0}$ to 1, however, it appears that the use of smaller and presumably lower-affinity protein-binding domains leads to a narrower site spacing tolerance. In general, larger higher-affinity proteinbinding domains may tolerate suboptimal linker distances and may generate more promiscuous protein-DNA dimerizers.

Finally, to determine the principal role of the lysine in the WMK tripeptide conjugates 9 and 10, their lysine side-chains were acetylated to create conjugates 13 and 14, respectively. These compounds retain the same linker length as $\mathbf{9}$ and $\mathbf{1 0}$ between the polyamide and the core WM dipeptide, but should eliminate the positive charge on the lysine while maintaining comparable steric bulk. Both $\mathbf{1 3}$ and $\mathbf{1 4}$ were not able to form a complex in the presence of Exd (Supplemental Figure 4c). This suggests that the lysine side-chain makes a favorable electrostatic interaction to stabilize the Exd-DNA-dimerizer complex. Although a direct interaction with the Exd protein cannot be ruled out, the presumed requirement for the linker domain to traverse the DNA backbone suggests that the primary role of this lysine group may be to interact favorably with the negatively charged phosphate groups of DNA. In comparing to natural systems it was observed that Ubx contains an alanine at this position, ${ }^{7 \mathrm{a}}$ but lysine and arginine are often found immediately adjacent to the C-terminal end of the YPWM motif in many HOX proteins. ${ }^{10}$

\section{Calculation of Distances}

The superposition of a polyamide crystal structure ${ }^{11}$ (PDB code 365D) over specific DNA sites in the Ubx/Exd/DNA crystal structure ${ }^{7 a}$ (PDB code 1B8I) readily allows the measurement of theoretical distances between the polyamide tail and the YPWM peptide that the linker domain must traverse (Figure 6 and Tables 1 and 2). In the proximal orientation the shortest distance occurs somewhere between the 2 and 3 bp spacings ( 11 $\AA$ ) and increases in both directions in a non-linear fashion due to the helical nature of the DNA grooves. In the distal orientation, the polyamide positions the linker past the minimum distance of approximately 11 $\AA$ Abserved in the proximal orientation. Thus, even at a 2 bp overlap in the distal orientation the distance is approximately $15 \AA$, which is longer than the shortest distance in the proximal orientation.

The results cannot be completely rationalized using distance measurements, however. For instance, comparing proximal sites with spacers of similar distances, such as 1 and 4 bps (14$15 \AA$ ), or 0 and 5 bps $(19-20 \AA$ ) reveal that sites with similar distance constraints do not necessarily lead to similar abilities to enhance Exd binding to DNA. This apparent discrepancy could be explained by the fact that the measured distances do not account for the interference by the phosphate backbone which the linker domain must cross to place the protein-binding domain in the necessary location. Additionally, the linker domain must bend back 
approximately $180^{\circ}$ in the 1 and 0 bp sites to bring the protein-binding domain into the correct binding orientation whereas the 4 and 5 bp sites project the protein-binding domain directly toward its Exd binding pocket. Such bending of the linker domain may be energetically unfavorable.

Similarly, in spite of the overlapping range of possible distances for the distal binding orientations $(\sim 11-30 \AA$ ) when compared to the proximal sites $(\sim 15-30 \AA)$, only the -2 bp distal site led to a stable complex with Exd. Unfortunately, greater overlap sites in the distal orientation cannot be addressed without changing the structure of the polyamide which was held constant for the purposes of this study. Movement of the polyamide binding site to the -3 bp site may still lead to a functional binding orientation, but the overlapped $-4 \mathrm{bp}$ site will probably not be tolerated since Arg2 of the Exd homeodomain contacts the thymine base at this location in the minor groove. ${ }^{7 a}$

Interestingly, a complex was observed at the $6 \mathrm{bp}$ (strong complex) and $7 \mathrm{bp}$ (weak complex) proximal arrangements ( $\geq 25 \AA$ spacing) with compound 1 even though the fully extended linker $(\sim 23 \AA)$ was predicted not to reach in either case. This suggests there may have been some structural adaptation by the complex to enable the YPWM-Exd interaction. It is noted that TATA DNA sequences are known to be bent by TATA-binding protein ${ }^{12}$ and it is thought that such sequences are inherently flexible. ${ }^{13}$ Thus, the use of a variable poly-AT spacer may have enabled such DNA distortions. Either the Exd structure or the placement of the YPWM peptide in the Exd binding pocket may also allow structural deviations.

\section{Conclusions}

A set of linear polyamide-peptide conjugates have been created which expand the recognition scope of protein-DNA dimerizers targeted towards Exd. In particular, conjugate 1 was shown to enhance Exd's binding to DNA when the protein and polyamide binding sites were -2, 2, $3,4,5$, and 6 bps apart. We have previously reported branched dimerizers that facilitate Exd binding to $-1,5 \mathrm{c} 0,5$ and $1 \mathrm{bp}^{5 \mathrm{c}}$ orientations. Thus, a set of solutions from -2 to 6 bps has been completed using these linear conjugates. Furthermore, the protein-binding domain was minimized to a WMK tripeptide (9 and 10) that functioned nearly as well as the larger conjugates (1 and $\mathbf{2}$ ). Remarkably, the range of tolerated orientations appears to be tunable not only by the length and chemical nature of the linker (compare $\mathbf{1}$ to $\mathbf{2}$ ), but also by the content of the protein-binding domain (compare $\mathbf{1}$ to $\mathbf{9}$ ).

In combination with the previous results for branched dimerizers, ${ }^{5}$ the work presented here provides design principles for dimerizers suitable for use in cell culture and fruit fly experiments. Developmental processes in fruit flies have been perturbed using polyamides. 14 The question arises whether a linear or branched protein-DNA dimerizer can interfere specifically with the normal function of Exd and lead to distinct fruit fly phenotypes. All compounds in this study function at temperatures suitable for experiments in fruit flies $\left(20^{\circ}\right.$ C) and the unnatural D-Trp WMK conjugate (10) is expected to be resistant to endogenous proteases. 15

The unique availability of multiple high-resolution structural models of HOX-DNA complexes provided a notable advantage for the design and refinement of these dimerizers. The growing number of high-resolution structures of multiprotein-DNA complexes should facilitate the design of additional protein-DNA dimerizers that function in other systems. Thus, there is a need for further structural studies on protein-DNA complexes that should aid the development of these molecules. This structure-based design approach contrasts with the screening efforts used for the development of small activation domains for other artificial transcription factors due to the paucity of such high-resolution models. $4 \mathrm{~h}-\mathrm{i}, 17$ 


\section{Experimental Section}

\section{General}

Fmoc protected amino acids and 2-chlorotritylchloride resin was purchased from Novabiochem. Super Acid Sensitive Resin (SASRIN ${ }^{\mathrm{TM}}$ ) was purchased from Bachem. Boc- $\beta$ Ala-PAM resin was purchased from Peptides International. Trifluoroacetic acid (TFA) was purchased from Halocarbon. Molecular biology grade ethylenediaminetetraactic acid (EDTA), potassium glutamate, and acetylated BSA were purchased from Sigma. DTT was purchased from ICN. Other chemicals were purchased from Aldrich or EM Sciences and used without further purification. All other solvents were purchased from EM Sciences and were reagent grade. Water $(18 \mathrm{M} \Omega)$ was purified using a Millipore MilliQ water purification system. Biological experiments were performed using Ultrapure Distilled Water (DNase/RNase free) purchased from Gibco. The $\mathrm{pH}$ of buffers was adjusted using a Beckman $340 \mathrm{pH} / \mathrm{Temp}$ Meter. All buffers were sterilized by filtration through either a Nalgene $0.2 \mu \mathrm{m}$ cellulose nitrate filtration device or a Pall Acrodisc ${ }^{\circledR}$ Syringe Filter HT Tuffryn ${ }^{\circledR}$ membrane $(0.2 \mu \mathrm{m})$. DNA oligonucleotides were obtained from Integrated DNA Technologies. $\left[\gamma-{ }^{32} \mathrm{P}\right]$-adenosine-5'triphosphate ( $\geq 6000 \mathrm{Ci} / \mathrm{mmol}$ ) was obtained from Perkin Elmer. Polynucleotide kinase (PNK) was obtained from Roche. UV spectra were recorded in water using an Agilent 8453 UVVisible spectrophotometer. All polyamide concentrations were determined using an extinction coefficient $\varepsilon=69,500 \mathrm{M}^{-1} \cdot \mathrm{cm}^{-1}$ at a $\lambda_{\max }$ near $310 \mathrm{~nm}$. Matrix-assisted, LASER desorption/ ionization time of flight mass spectrometry (MALDI-TOF MS) was performed using a Applied Biosystems Voyager DE Pro Spectrometer. Electrospray ionization (ESI) mass spectrometry was performed using a Finnigan LCQ ion trap mass spectrometer. Analytical High-Pressure Liquid Chromatography (HPLC) was performed with a Beckman Gold system equipped with a diode array 168 Detector and a 125 Solvent module using a Phenomenex Gemini $\mathrm{C}_{18}$ column (5 $\mu \mathrm{m}$ particle size, $250 \times 4.60 \mathrm{~mm}$ ). Preparative HPLC was performed with a Beckman Gold system equipped with a 127P Solvent Module and a single wavelength 166P Detector monitoring $310 \mathrm{~nm}$ using a Waters DeltaPak $\mathrm{C}_{18}$ reverse phase column (100 $\mu \mathrm{m}$ particle size, $25 \times 100 \mathrm{~mm})$ or a Phenomenex Gemini $\mathrm{C}_{18}$ reverse phase column ( $5 \mu \mathrm{m}$ particles, $110 \AA$ A pore, $250 \times 21.2 \mathrm{~mm}$ ). For both analytical and preparative HPLC, solvent A was $0.1 \%(\mathrm{v} / \mathrm{v})$ aqueous TFA and solvent $B$ was acetonitrile. In general, compound purity was assessed using an HPLC analytical method employing a gradient of $\sim 4.12 \% \mathrm{~B} / \mathrm{min}$ starting from $10 \% \mathrm{~B}$ with a flow rate of $1.5 \mathrm{~mL} / \mathrm{min}$. Final preparative HPLC purification was performed by ramping from 10 $55 \%$ B over 75 min using the Gemini column. If the purity of the compound was less than $95 \%$, a second HPLC purification was performed employing a slow gradient through the previous \% B elution of the compound.

\section{Synthesis}

Polyamide monomers were prepared as described previously. ${ }^{18}$ Polyamides were synthesized according to standard synthetic procedures, ${ }^{18}$ and cleaved from the resin with either 3,3'diamino- $N$-methyl-dipropylamine, 4,7,10-trioxa-1,13-tridecanediamine, or 3(dimethylamino)-propylamine. Before conjugation to peptides, polyamides were HPLC purified and characterized by MALDI-TOF MS, UV-Vis spectroscopy, and analytical HPLC. Protected peptides were synthesized using SASRIN or 2-chlorotrityl resin using standard Fmoc protocols 19 and characterized by ESI MS and analytical HPLC. Polyamide-peptide conjugates were prepared as described previously using 0.1 M DIEA in DMF using excess PyBOP $(\sim 5$ equiv) followed by deprotection with $80 \%$ TFA, $5 \%$ TIS, $5 \%$ EDT, and 10\% DCM. ${ }^{5 a}$ Conjugates were then purified by preparative HPLC and characterized by MALDI-TOF or ESI MS, UV-Vis spectroscopy, and analytical HPLC. 1: (MALDI-TOF) [M+H] calcd for $\mathrm{C}_{113} \mathrm{H}_{146} \mathrm{~N}_{31} \mathrm{O}_{19} \mathrm{~S}$ 2274.1, observed 2274.0; 2: (MALDI-TOF) [M+H] calcd for $\mathrm{C}_{116} \mathrm{H}_{151} \mathrm{~N}_{30} \mathrm{O}_{22} \mathrm{~S}$ 2349.1, observed 2349.0; 3: (MALDI-TOF) [M+H] calcd for $\mathrm{C}_{103} \mathrm{H}_{137} \mathrm{~N}_{30} \mathrm{O}_{19}$ 2099.1, observed 2098.8; 4: (MALDI-TOF) [M+H] calcd for 
$\mathrm{C}_{106} \mathrm{H}_{142} \mathrm{~N}_{29} \mathrm{O}_{22} 2174.1$, observed 2174.0; 5: (ESI) [M+H] calcd for $\mathrm{C}_{84} \mathrm{H}_{109} \mathrm{~N}_{26} \mathrm{O}_{14} \mathrm{~S}$ 1737.8, observed 1737.6; 6: (MALDI-TOF) [M+H] calcd for $\mathrm{C}_{84} \mathrm{H}_{109} \mathrm{~N}_{26} \mathrm{O}_{14} \mathrm{~S} 1737.8$, observed 1737.4; 7: (ESI) [M+H] calcd for $\mathrm{C}_{87} \mathrm{H}_{114} \mathrm{~N}_{25} \mathrm{O}_{17} \mathrm{~S}$ 1812.9, observed 1812.5; 8: (MALDITOF) [M+Na] calcd for $\mathrm{C}_{87} \mathrm{H}_{113} \mathrm{~N}_{25} \mathrm{O}_{17} \mathrm{SNa}$ 1834.8, observed 1834.6; 9: (MALDI-TOF) [M $+\mathrm{H}]$ calcd for $\mathrm{C}_{90} \mathrm{H}_{121} \mathrm{~N}_{28} \mathrm{O}_{15} \mathrm{~S}$ 1865.9, observed 1865.5; 10: (MALDI-TOF) [M+H] calcd for $\mathrm{C}_{90} \mathrm{H}_{121} \mathrm{~N}_{28} \mathrm{O}_{15} \mathrm{~S}$ 1865.9, observed 1865.8; 11: (MALDI-TOF) [M+H] calcd for $\mathrm{C}_{93} \mathrm{H}_{126} \mathrm{~N}_{27} \mathrm{O}_{18} \mathrm{~S}$ 1941.0, observed 1941.0; 12: (MALDI-TOF) [M+H] calcd for $\mathrm{C}_{93} \mathrm{H}_{126} \mathrm{~N}_{27} \mathrm{O}_{18} \mathrm{~S}$ 1941.0, observed 1940.9. Acetylated compounds $\mathbf{1 3}$ and $\mathbf{1 4}$ were synthesized by treating 200-300 nmol of $\mathbf{9}$ and 10, respectively, with 8-9 equivalents of acetic anhydride in 0.1 M DIEA in DMF and purified by preparative HPLC. 13: (MALDI-TOF) [M+H] calcd for $\mathrm{C}_{92} \mathrm{H}_{123} \mathrm{~N}_{28} \mathrm{O}_{16} \mathrm{~S}$ 1907.9, observed 1908.2; 14: (MALDI-TOF) [M+H] calcd for $\mathrm{C}_{92} \mathrm{H}_{123} \mathrm{~N}_{28} \mathrm{O}_{16} \mathrm{~S}$ 1907.9, observed 1908.0; 15: (MALDI-TOF) [M+H] calcd for $\mathrm{C}_{58} \mathrm{H}_{72} \mathrm{~N}_{21} \mathrm{O}_{10}$ 1222.6, observed 1222.7.

\section{Preparation of ${ }^{32} \mathrm{P}$-labeled DNA duplexes}

DNA oligos were first annealed by heating to $95^{\circ} \mathrm{C}$ for $5 \mathrm{~min}$ and allowing the solution to cool slowly to room temperature for $\sim 2-3$ hours. The dsDNA duplexes were then $5^{\prime}$-labeled using polynucleotide kinase using the manufacturer's protocols. Labeled duplexes were purified by gel electrophoresis and band extraction from a $6 \%$ nondenaturing polyacrylamide gel, diluted to $10 \mathrm{kpcm} / \mu \mathrm{L}$, stored at $-78^{\circ} \mathrm{C}$, and used within 2 weeks.

\section{Electrophoretic Mobility Shift Assays (EMSAs)}

EMSA, or gel shift, experiments were performed at $20{ }^{\circ} \mathrm{C}$ as described previously. $5 \mathrm{~d}$ Polyamide conjugates were pre-incubated with $\sim 5 \mathrm{kcpm} /$ reaction of ${ }^{32} \mathrm{P}$-labeled duplexes (4655 bps, Supplemental Figures 6 and 7) at room temperature $\left(20^{\circ} \mathrm{C}\right)$ in buffer for $1 \mathrm{~h}$. Exd protein was then added to the reaction solution and the solution was allowed to equilibrate for an additional hour. The final concentrations of the components were $50 \mathrm{nM}$ of the indicated compound, $30 \mathrm{mM}$ potassium glutamate, $10 \mathrm{mM}$ HEPES, $0.2 \mathrm{mM}$ DTT, $10 \%$ glycerol, and $0.1 \mathrm{mg} / \mathrm{mL}$ acetylated BSA. The final concentrations for Exd were the following: $10 \mathrm{pM}, 50$ $\mathrm{pM}, 100 \mathrm{pM}, 500 \mathrm{pM}, 1 \mathrm{nM}, 5 \mathrm{nM}, 10 \mathrm{nM}, 50 \mathrm{nM}$, and $100 \mathrm{nM}$. A volume of $10 \mu \mathrm{L}$ of the solution was loaded onto a, pre-run (15 $\mathrm{min}$ ) non-denaturing 9\% polyacrylamide (29:1 acrylamide:bisacrylamide $/ 3 \%$ glycerol, 1 X TBE) $0.8 \mathrm{~mm}$ thick gel and developed at $180-190 \mathrm{~V}$ and $13-15 \mathrm{~mA}$ for $1.5 \mathrm{~h}$ at room temperature. Gels were then dried and exposed to a phosphor screen overnight, which were scanned by a Molecular Dynamics 400S phosphorimager. Recombinant Exd (residues 238-320) was expressed ${ }^{5}$ and characterized ${ }^{5 \mathrm{~d}}$ as described previously. The Exd concentration was determined by measuring the UV absorption at $280 \mathrm{~nm}$ using a calculated ${ }^{20}$ extinction coefficient of $12,600 \mathrm{M}^{-1} \cdot \mathrm{cm}^{-1}$. The amount of Exd bound to the DNA template was determined as described previously $5 \mathrm{~d}$ and fit to the Hill equation 21 with $\mathrm{n}=1$. All binding affinities were measured in triplicate.

\section{Theoretical distance measurements}

The illustrative models shown in Figure 6 were created by superimposing the DNA backbone of the atomic coordinates from a representative polyamide-DNA crystal structure ${ }^{11}$ (PDB code 365D) over the desired site on the DNA backbone from the Ubx/Exd/DNA crystal structure $^{7 \mathrm{a}}$ (PDB code 1B8I) using a fit algorithm from SwissPDB Viewer (ver 3.7). The DNA from the polyamide crystal structure and the Ubx homeodomain were then deleted to generate a model from which the distance measurements were be made.

The illustrative models shown in Figure 7 were made by first superimposing a polyamide-DNA crystal structure as described above. The linker between the polyamide and the FYPWMA peptide from Ubx, the linker, and the $\gamma$-aminobutyric acid of the polyamide hairpin, the lysine side-chain, and the acetyl moiety were constructed and minimized using an augmented MM3 
force field and short molecular dynamics simulations ( $<100 \mathrm{ps})$ with all other coordinates locked using CAChe Workspace (ver. 6.1.12.33). The DNA shown in the figure is the same as the DNA from the Ubx/Exd/DNA structure.

\section{Supplementary Material}

Refer to Web version on PubMed Central for supplementary material.

\section{Acknowledgements}

This work was supported by the National Institute of Health (NIH GM51747 to P.B.D.). A fellowship from the Rose Hills Foundation (to R.L.S.) is gratefully acknowledged. We thank Drs. P. Snow and G. Hathaway (Beckman Institute, California Institute of Technology) for technical assistance with protein expression, purification, and identification.

\section{References}

1. (a) Mitchell PJ, Tjian R. Science 1989;245:371-378. [PubMed: 2667136] (b) Lee TI, Young RA. Annu Rev Genet 2000;34:77-137. [PubMed: 11092823] (c) Kadonaga JT. Cell 2004;116:247-257. [PubMed: 14744435] (d) Levine M, Tjian R. Nature 2003;424:147-151. [PubMed: 12853946]

2. (a) Klemm JD, Schreiber SL, Crabtree GR. Annu Rev Immunol 1998;16:569-592. [PubMed: 9597142] (b) Wolberger C. Annu Rev Biophys Biomol Struct 1999;28:29-56. [PubMed: 10410794] (c) Ogata K, Sato K, Tahirov T. Curr Opin Struct Biol 2003;13:40-48. [PubMed: 12581658]

3. Ptashne, M.; Gann, A. Genes \& Signals. Cold Spring Harbor Laboratory Press; Plainview, NY: 2002.

4. (a) Kuznetsova S, Ait-Si-Ait S, Nagibneva I, Troalen F, Le Villain J, Harel-Bellan A, Svinarchuk F. Nucleic Acids Res 1999;27:3995-4000. [PubMed: 10497263] (b) Mapp AK, Ansari AZ, Ptashne M, Dervan PB. Proc Natl Acad Sci USA 2000;97:3930-3935. [PubMed: 10760265] (c) Ansari AZ, Mapp AK, Nguyen DH, Dervan PB, Ptashne M. Chem Biol 2001;8:583-592. [PubMed: 11410377] (d) Liu B, Han Y, Corey DR, Kodadek T. J Am Chem Soc 2002;124:1838-1839. [PubMed: 11866581] (e) Stanojevic D, Young RA. Biochemistry 2002;41:7209-7216. [PubMed: 12044151] (f) Arora PS, Ansari AZ, Best TP, Ptashne M, Dervan PB. J Am Chem Soc 2002;124:13067-13071. [PubMed: 12405833] (g) Liu B, Han Y, Ferdus A, Corey DR, Kodadek T. Chem Biol 2003;10:909-916. [PubMed: 14583257] (h) Kwon Y, Arndt HD, Mao Q, Choi Y, Kawazoe Y, Dervan PB, Uesugi M. J Am Chem Soc 2004;126:15940-15941. [PubMed: 15584709] (i) Xiao X, Yu P, Lim HS, Sikder D, Kodadek T. Angew Chem, Int Ed 2007;46:2865-2868.For reviews, see: (j) Ansari AZ, Mapp AK. Curr Opin Chem Biol 2002;6:765-772. [PubMed: 12470729] (k) Arndt HD. Angew Chem, Int Ed 2006;45:4552-4560.

5. (a) Arndt HD, Hauschild KE, Sullivan DP, Lake K, Dervan PB, Ansari AZ. J Am Chem Soc 2003;125:13322-13323. [PubMed: 14583004] (b) Hauschild KE, Metzler RE, Arndt HD, Moretti R, Raffaelle R, Dervan PB, Ansari AZ. Proc Natl Acad Sci USA 2005;102:5008-5013. [PubMed: 15781856] (c) Warren CL, Kratochvil NCS, Hauschild KE, Foister S, Brezinski ML, Dervan PB, Phillips GN Jr, Ansari AZ. Proc Natl Acad Sci USA 2006;103:867-872. [PubMed: 16418267] (d) Stafford RL, Arndt HD, Brezinski ML, Ansari AZ, Dervan PB. J Am Chem Soc 2007;129:2660-2668. [PubMed: 17290996]

6. (a) Peifer M, Wieschaus E. Genes Dev 1990;4:1209-1223. [PubMed: 1976570] (b) Chan SK, Jaffe L, Capovilla M, Botas J, Mann RS. Cell 1994;78:603-615. [PubMed: 7915199] (c) van Dijk MA, Murre C. Cell 1994;78:617-624. [PubMed: 7915200] (d) Mann RS, Chan SK. Trends Genet 1996;12:258262. [PubMed: 8763497]

7. (a) Passner JM, Ryoo HD, Shen LY, Mann RS, Aggarwal AK. Nature 1999;397:714-719. [PubMed: 10067897] (b) Piper DE, Batchelor AH, Chang CP, Clearly ML, Wolberger C. Cell 1999;96:587-597. [PubMed: 10052460] (c) LaRonde-LeBlanc NA, Wolberger C. Genes Dev 2003;17:2060-2072. [PubMed: 12923056]

8. (a) Dervan PB. Bioorg Med Chem 2001;9:2215-2235. [PubMed: 11553460] (b) Dervan PB, Edelson BS. Curr Opin Struct Biol 2003;13:284-299. [PubMed: 12831879] (c) Olenyuk BZ, Zhang GJ, Klco JM, Nickols NG, Kaelin WG, Dervan PB. Proc Natl Acad Sci USA 2004;101:16768-16773. [PubMed: 15556999] (d) Nickols NG, Dervan PB. Proc Natl Acad Sci USA 2007;104:10418-10423. [PubMed: 17566103] 
9. Kreuzer HJ, Wang RLC, Grunze M. New J Phys 1999;1:21.1-21.16.

10. Duboule, D., editor. Guidebook to the Homeobox Genes. Oxford University Press; Oxford: 1994.

11. Kielkopf CL, Baird EE, Dervan PB, Rees DC. Nat Struct Biol 1998;5:104-109. [PubMed: 9461074]

12. (a) Kim Y, Geiger JH, Hahn S, Sigler PB. Nature 1993;365:512-520. [PubMed: 8413604] (b) Kim JL, Nikolov DB, Burley SK. Nature 1993;365:520-527. [PubMed: 8413605] (c) Kim JL, Burley SK. Nat Struct Biol 1994;1:638-653. [PubMed: 7634103] (d) Juo ZS, Chiu TK, Leiberman PM, Baikalov I, Berk AJ, Dickerson RE. J Mol Biol 1996;261:239-254. [PubMed: 8757291]

13. Davis NA, Majee SS, Kahn JD. J Mol Biol 1999;291:249-265. [PubMed: 10438619]

14. (a) Janssen S, Durussel T, Laemmli UK. Mol Cell 2000;6:999-1011. [PubMed: 11106740] (b) Janssen S, Cuvier O, Muller M, Laemmli UK. Mol Cell 2000;6:1013-1024. [PubMed: 11106741]

15. Direct observation of the cell uptake of these compounds is not possible using confocal microscopy without the conjugation of a fluorescent dye (see reference ${ }^{16}$ ), so we must infer cell uptake indirectly for compounds 1-15 from the biological data. Experiments with polyamide-peptide-fluorophore conjugates to assess cell uptake are underway.

16. (a) Belistky JM, Leslie SJ, Arora PS, Beerman TA, Dervan PB. Bioorg Med Chem 2002;10:33133318. [PubMed: 12150878] (b) Best TP, Edelson BS, Nickols NG, Dervan PB. Proc Natl Acad Sci USA 2003;100:12063-12068. [PubMed: 14519850] (c) Edelson BS, Best TP, Olenyuk B, Nickols NG, Doss RM, Foister S, Heckel A, Dervan PB. Nucleic Acids Res 2004;32:2802-2818. [PubMed: 15155849]

17. Minter AR, Brennan BB, Mapp AK. J Am Chem Soc 2004;126:10504-10505. [PubMed: 15327284]

18. Baird EE, Dervan PB. J Am Chem Soc 1996;118:6141-6146.

19. Wellings DA, Atherton E. Methods Enzymol 1997;289:44-67. [PubMed: 9353717]

20. Gill SC, von Hippel PH. Anal Biochem 1989;182:319-326. [PubMed: 2610349]

21. Cantor, CR.; Schimmel, PR. Biophysical Chemistry of Macromolecules, Part 3: The Behavior of Biological Macromolecules. W. H. Freeman and Company; New York: 1980. 
(a)

branched

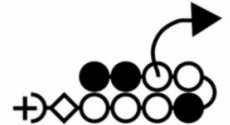

linear

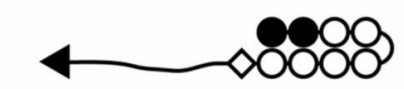

(b)

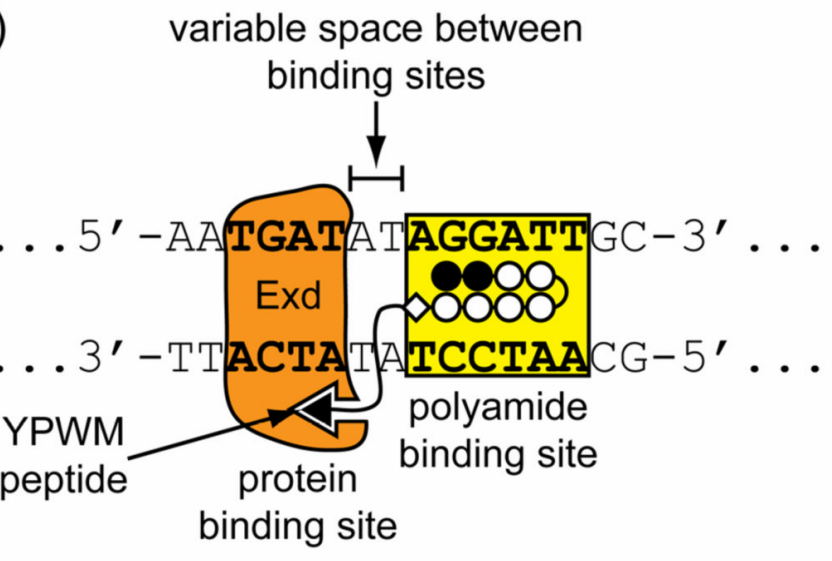

(c)

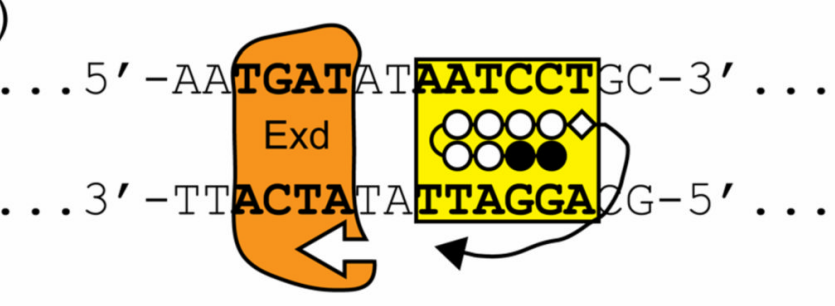

(d)

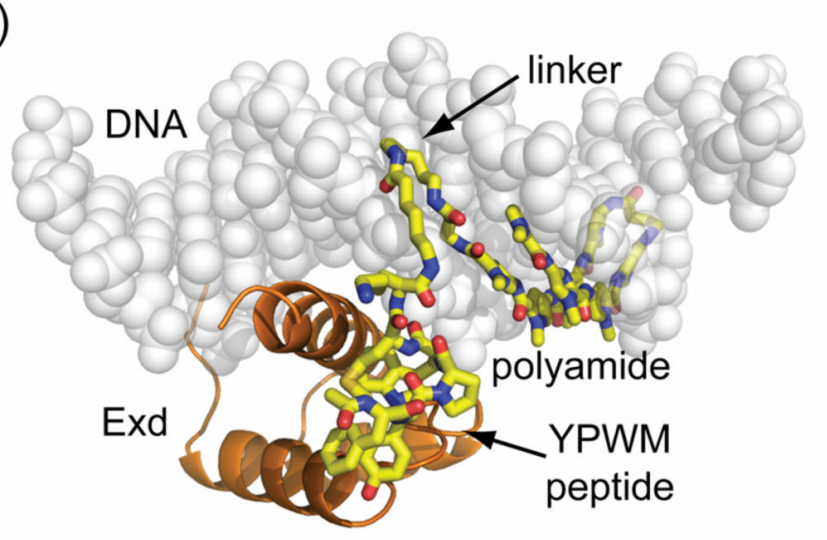

Figure 1.

Design of linear protein-DNA dimerizers. (a) Comparison of branched polyamide-peptide conjugates to linear conjugates, both used as protein-DNA dimerizers for Exd. (open circles = $N$-methylpyrrole, dark circles $=N$-methylimidazole, half circle $=\gamma$-aminobutyric acid, diamond $=\beta$-alanine, half-circle with plus $=N, N$-dimethylaminopropylamine, free-hand line $=$ linker domain, and black triangle = protein-binding domain). (b) Diagram of a linear conjugate in the proximal orientation with the protein-binding domain directed toward Exd's DNA-binding site. (c) Diagram of a linear conjugate in the distal orientation with the protein-binding domain directed away from Exd's DNA-binding site. (d) An illustrative model of the linear proteinDNA dimerizer 1 in complex with Exd and DNA as shown schematically in panel b. 


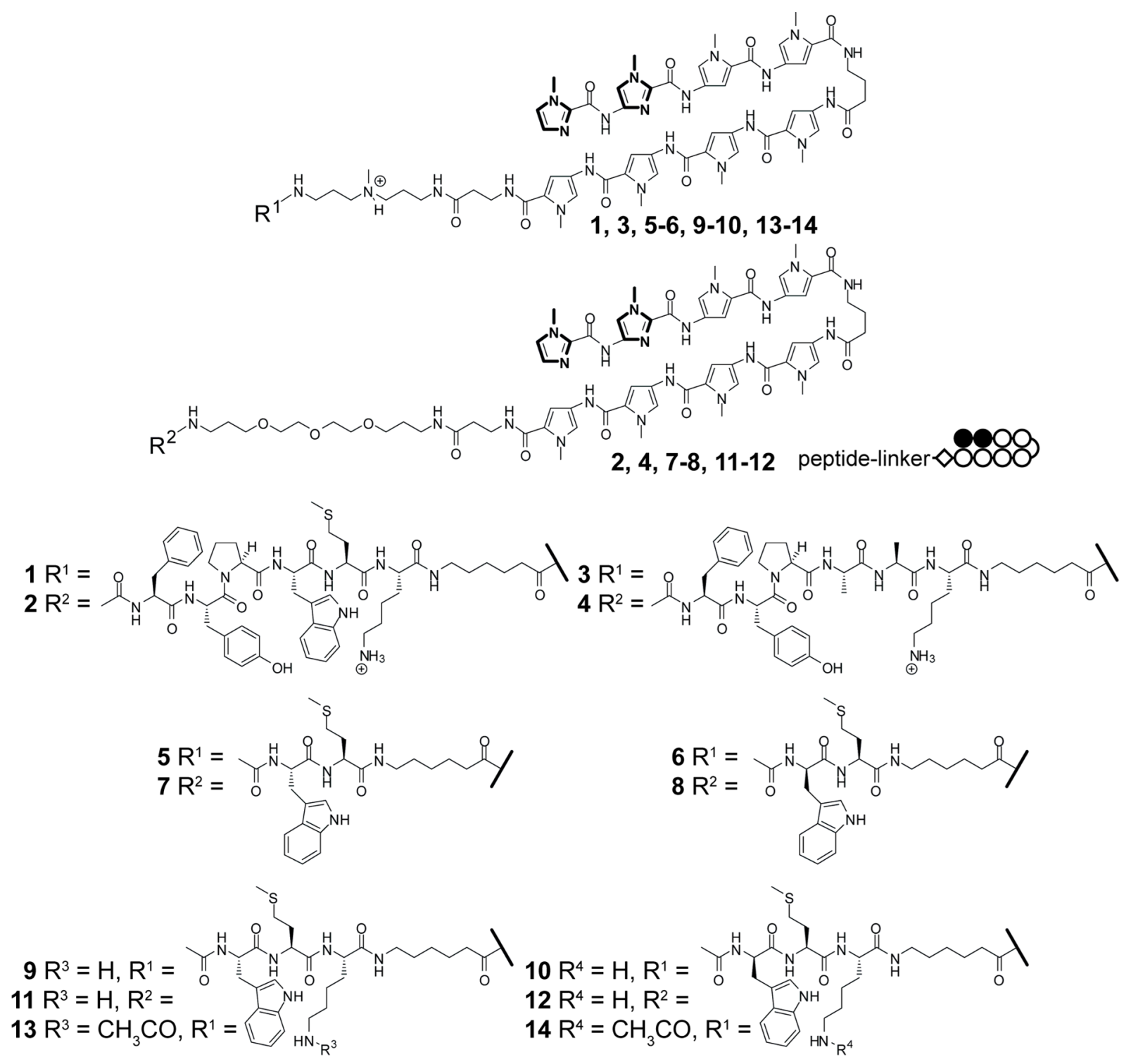

Figure 2.

Structures of compounds 1-14. 

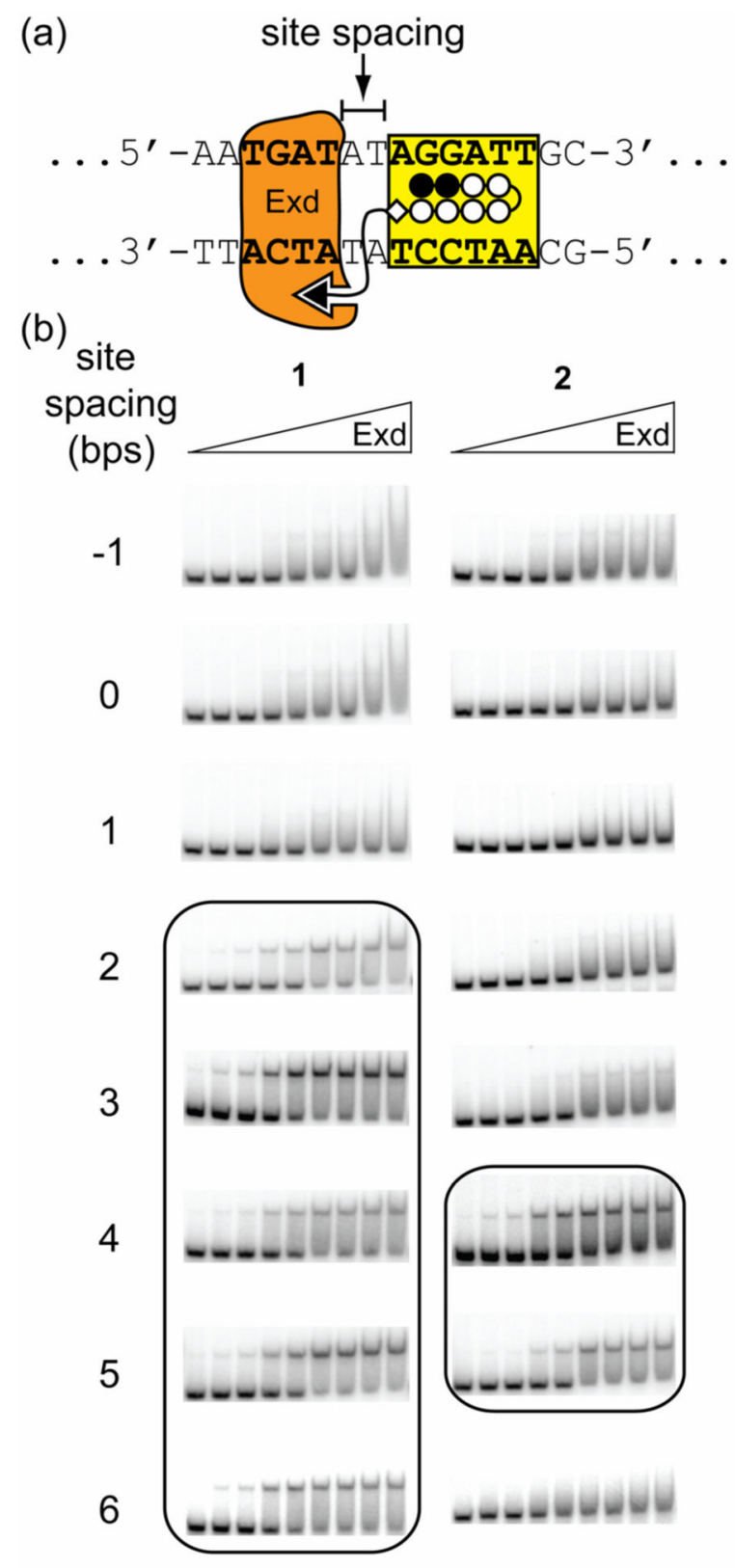

7 -
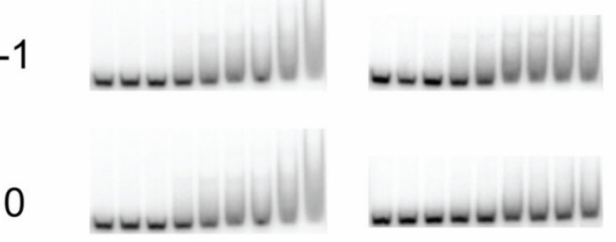

Figure 3.

Representative gel shift results for Exd in the presence of linear protein-DNA dimerizers with differently sized linkers on two proximally-oriented DNA sites. Conjugate $\mathbf{1}$ has an aminecontaining linker ( $23 \AA$ long) and conjugate 2 has a PEG-type linker ( $30 \AA$ long). (a) Schematic of the positions of the Exd and polyamide DNA-binding sites showing the A,T spacer region which was varied. (b) Gel shift experiments show that $\mathbf{1}$ forms a stable complex with Exd and DNA with site spacings between 2-6 bps, whereas 2 only forms stable complexes from 4-5 bps. A concentration of $50 \mathrm{nM}$ of the indicated compound was added to all lanes and the concentration of Exd from left to right is $10 \mathrm{pM}, 50 \mathrm{pM}, 100 \mathrm{pM}, 500 \mathrm{pM}, 1 \mathrm{nM}, 5 \mathrm{nM}, 10$ $\mathrm{nM}, 50 \mathrm{nM}$, and $100 \mathrm{nM}$. 


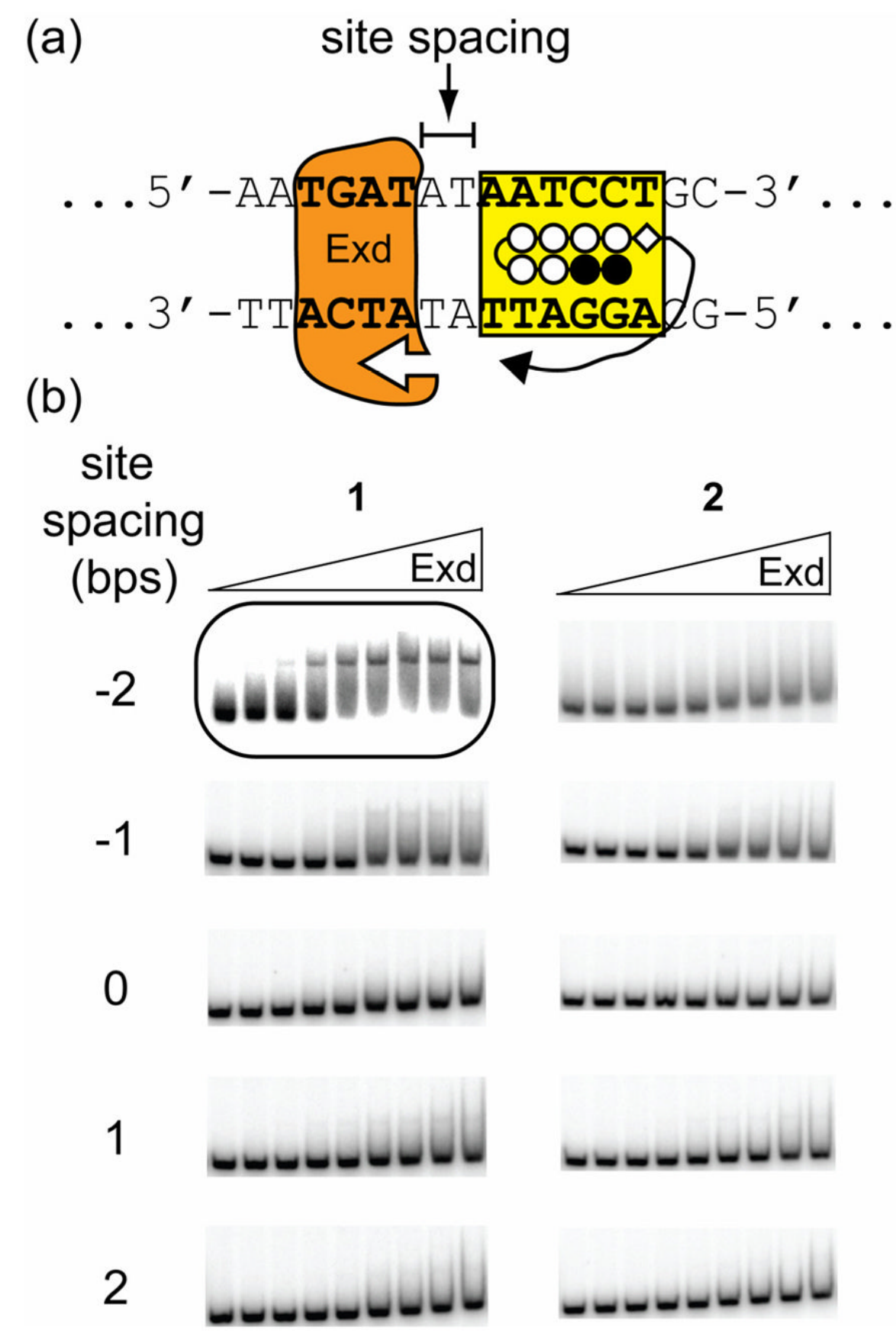

Figure 4.

Representative gel shift results for Exd in the presence of linear protein-DNA dimerizers with differently sized linkers on two distally-oriented DNA sites. (a) Schematic of the positions of the Exd and polyamide DNA-binding sites showing the A,T spacer region which was varied. (b) Gel shift experiments show that $\mathbf{1}$ forms a stable complex with Exd and DNA when there is a 2 bp overlap, i.e. a site spacing of -2 , between the two sites, whereas 2 does not form a complex with Exd at any of these sites. Concentrations of the compounds and Exd are the same as described in Figure 3. 

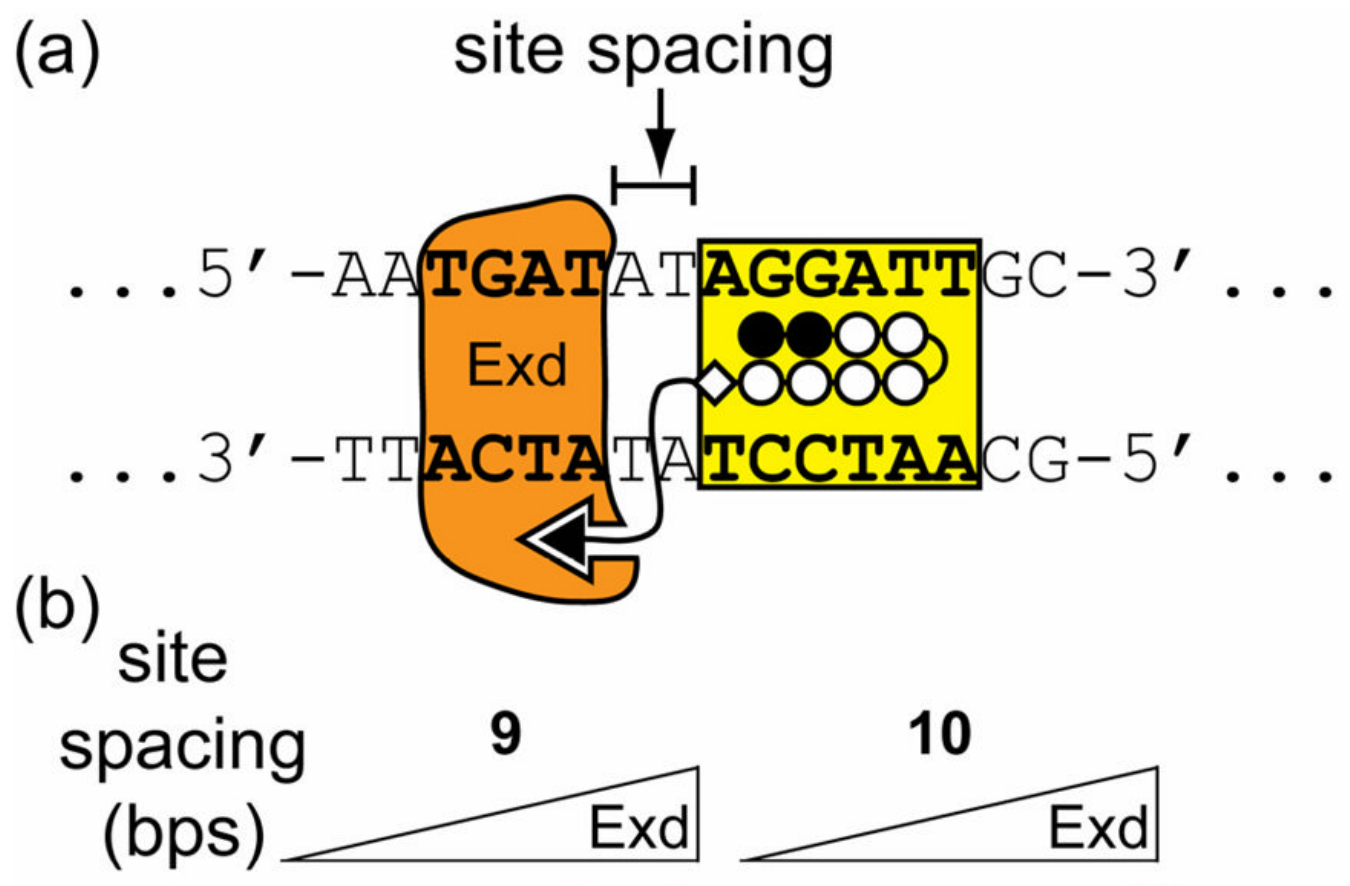

3
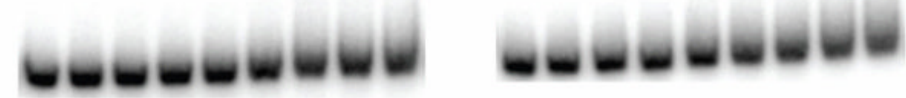

4
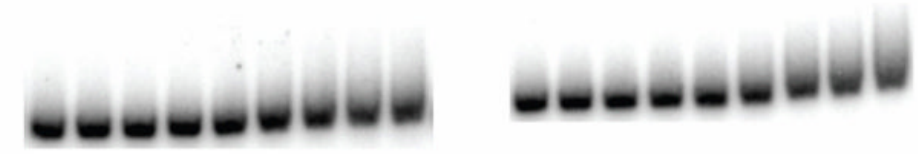

5
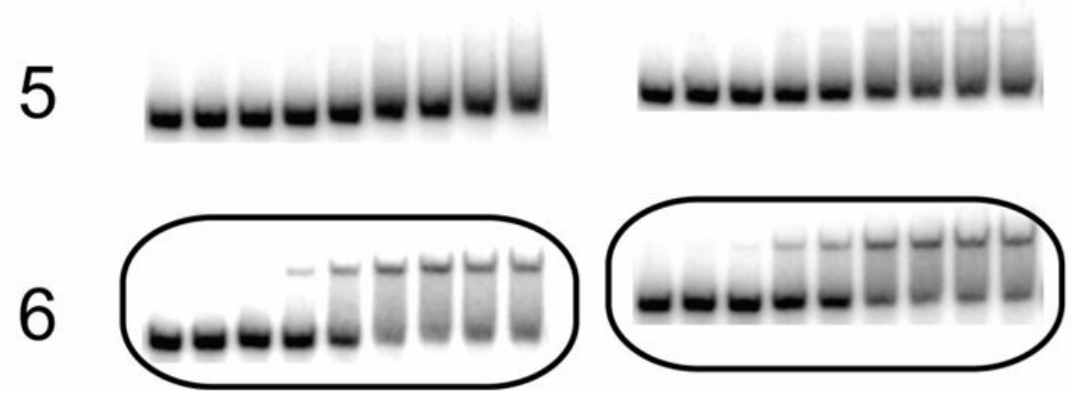

Figure 5.

Representative gel shift results for Exd in the presence of linear WMK tripeptide conjugates on select proximally-oriented DNA sites. (a) Schematic of the positions of the Exd and polyamide DNA-binding sites showing the A,T spacer region which was varied. (b) Gel shift experiments show that both $\mathbf{9}$ and $\mathbf{1 0}$ form stable complexes with Exd and DNA only when there is a $6 \mathrm{bp}$ site spacing. Concentrations of the compounds and Exd are the same as described in Figure 3. 

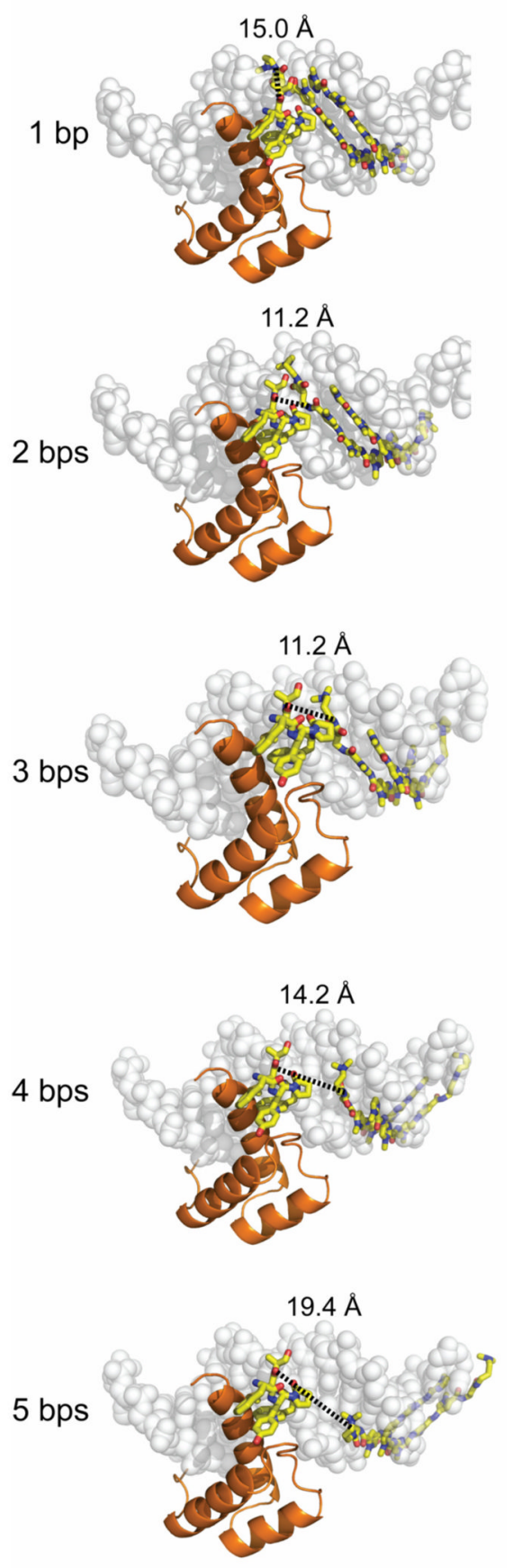

Figure 6.

A series of estimated distance measurements are shown between the polyamide tail and the methionine carbonyl of the YPWM protein-binding domain which each dimerizer linker domain must traverse. The models of the polyamides binding to the DNA were generated by superimposing the DNA-binding site from a representative polyamide-DNA crystal structure $(\mathrm{PDB}$ code $=365 \mathrm{D})$ over the Ubx/Exd/DNA crystal structure (PDB code 1B8I) and deleting the Ubx protein except for its YPWM protein-binding domain. In the proximal orientation, there exists a minimum distance of $\sim 11 \AA$ between the site spacings of 2-3 bps which increases non-linearly in each direction as the polyamide slides along the helical DNA minor groove. 


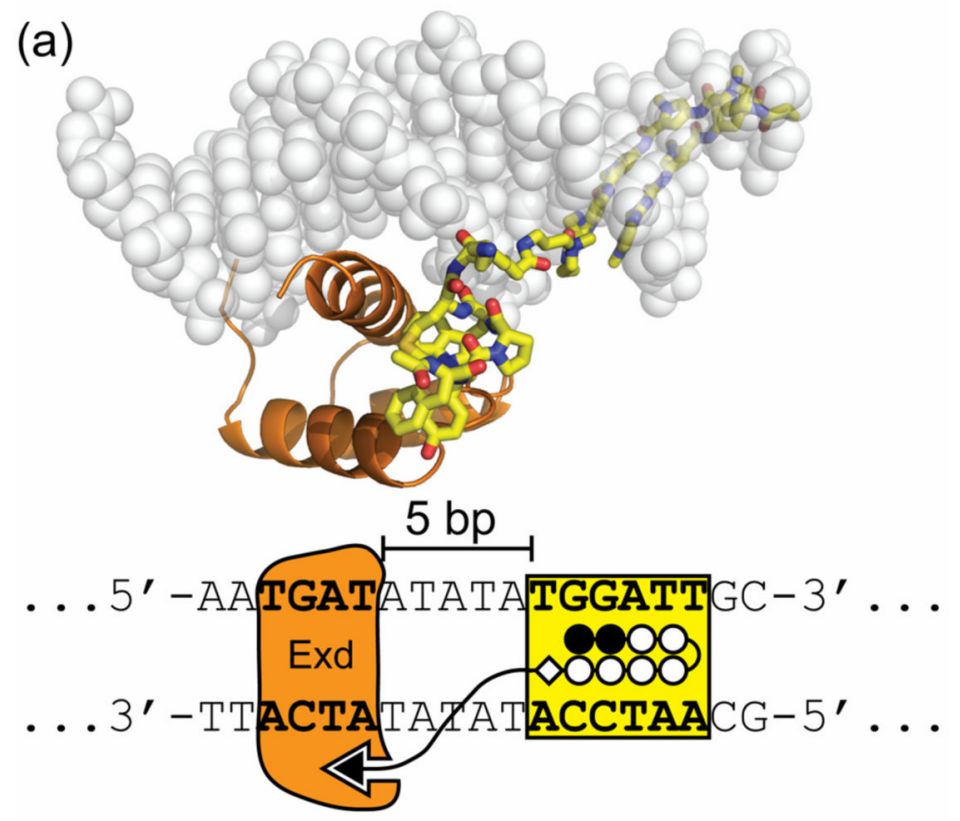

(b)

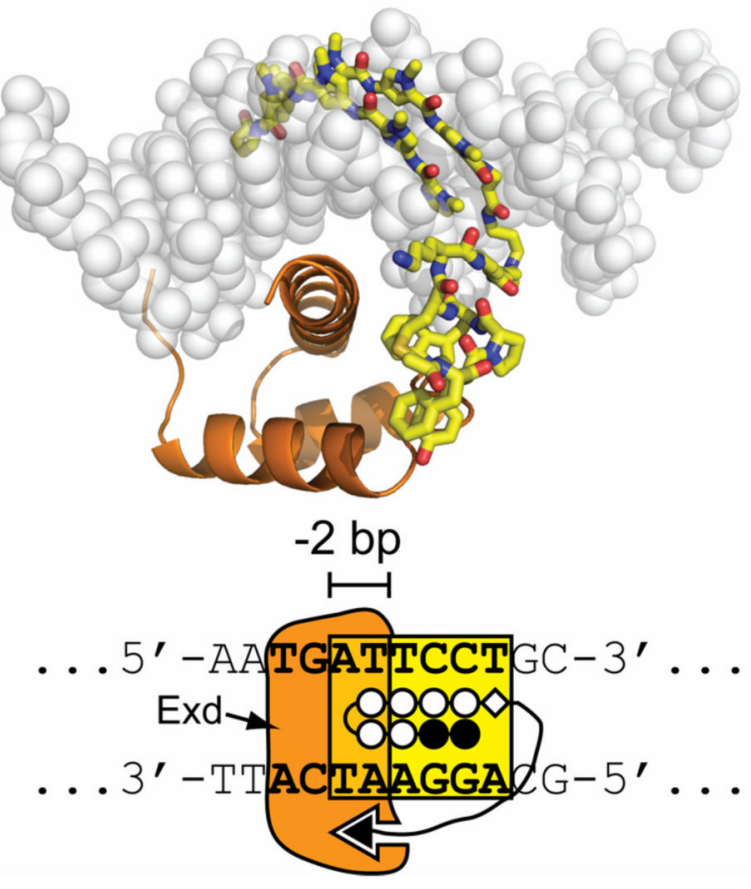

Figure 7.

Models of linear-protein DNA dimerizers. (a) A proximally-oriented binding site with a $5 \mathrm{bp}$ spacer with dimerizer 1 is shown. (b) A distally-oriented binding orientation with a 2 bp overlap (i.e. -2 bp spacer) between the polyamide and Exd DNA-binding sites is shown for dimerizer 1. 
Table 1

Summary of select proximal orientation gel shifts ${ }^{a}$

\begin{tabular}{cccc}
\hline $\begin{array}{c}\text { Base pairs between binding } \\
\text { sites }\end{array}$ & $\begin{array}{c}\text { Estimated proximal distance } \\
(\mathbf{\AA})\end{array}$ & Exd-DNA binding with 1 & Exd-DNA binding with 2 \\
\hline-1 & 23.8 & - & - \\
0 & 20.0 & - & - \\
1 & 15.0 & + & - \\
3 & 11.2 & + & $\mathbf{w}$ \\
4 & 11.2 & + & + \\
5 & 14.2 & + & - \\
7 & 19.4 & $\mathbf{w}$ & - \\
\hline
\end{tabular}

${ }^{a} \mathrm{~A}$ '+', 'w', and '-' indicate a strong, weak, or no complex, respectively. Binding constants ( $\mathrm{K}_{\mathrm{a}}$ 's) for '+' entries varied between $0.8 \pm 0.3$ to $2.7 \pm 1.0 \times$ $10^{9} \mathrm{M}^{-1}$ and the amount of complex formed was $\geq 0.4$ (Supplemental Figure 5). 
Table 2

Summary of select distal orientation gel shifts ${ }^{a}$

\begin{tabular}{|c|c|c|c|}
\hline $\begin{array}{c}\text { Base pairs between binding } \\
\text { sites }\end{array}$ & 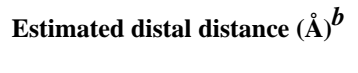 & Exd-DNA binding with 1 & Exd-DNA binding with 2 \\
\hline $\begin{array}{c}-2 \\
-1 \\
0 \\
1 \\
2\end{array}$ & $\begin{array}{r}15.1 \\
19.5 \\
23.8 \\
28.1 \\
31.5\end{array}$ & $\begin{array}{l}+ \\
- \\
- \\
- \\
-\end{array}$ & $\begin{array}{l}- \\
- \\
- \\
- \\
-\end{array}$ \\
\hline
\end{tabular}

